\title{
Production, characterization and toxicology assay of creatine pegylated nanoliposome with polysorbate 80 for brain delivery
}

\author{
DIEGO B. BORIN ${ }^{1}$, NATHANA J. MEZZOMO ${ }^{2}$, RODRIGO A. VAUCHER ${ }^{3}$, GUILHERME DO CARMO ${ }^{2}$, LUIZ C. \\ RODRIGUES JUNIOR ${ }^{4}$, FERNANDO B. SULCZEWSKI ${ }^{1}$, CLAITON I. SCHWERTZ ${ }^{5}$, RICARDO E. MENDES ${ }^{5}$, \\ ADRIANI P. DAMIANI ${ }^{6}$, VANESSA M. DE ANDRADE ${ }^{6}$, VIRGÍNIA C. RECH ${ }^{1}$ and CARINA R. BOECK ${ }^{1}$
}

\author{
${ }^{1}$ Centro Universitário Franciscano, Rua dos Andradas, 1614, Centro, 97010-032 Santa Maria, RS, Brazil \\ ${ }^{2}$ Universidade Federal de Santa Maria, Av. Roraima, 1000, Camobi, 97105-900 Santa Maria, RS, Brazil \\ ${ }^{3}$ Universidade Federal de Pelotas, Rua Gomes Carneiro, 1, Centro, 96010-610 Pelotas, RS, Brazil \\ ${ }^{4}$ Universidade Federal de Ciências da Saúde de Porto Alegre, Rua Sarmento Leite, \\ 245, Centro Histórico, 90050-170 Porto Alegre, RS, Brazil \\ ${ }^{5}$ Instituto Federal Catarinense, Rodovia SC 283, s/n, Vila Fragosos, 89700-000 Concórdia, SC, Brazil \\ ${ }^{6}$ Universidade do Extremo Sul Catarinense, Av. Universitária, 1105, Universitário, 88806-000 Criciúma, SC, Brazil
}

Manuscript received on July 20, 2017; accepted for publication on July 26, 2017

\begin{abstract}
Creatine acts intracellularly as energy buffer and storage, demonstrating protective effects in animal models of neurodegenerative diseases. However, its permeability throught blood-brain barrier (BBB) is reduced. The aim of the present study was developing a carrier to facilitate the delivery of creatine to the central nervous system. Creatine nanoliposomes were produced, characterized and assayed in models of toxicity in vitro and in vivo. Particles showed negative zeta potential $(-12,5 \mathrm{mV})$, polydispersity index 0.237 and medium-size of $105 \mathrm{~nm}$, which was confirmed by transmission electron microscopy (TEM) images. Toxicity assay in vitro was evaluated with blank liposomes (no drug) or creatine nanoliposomes at concentrations of 0.02 and $0.2 \mathrm{mg} / \mathrm{mL}$, that did not influence the viability of Vero cells. The result. of the comet assay that the nanoliposomes are not genotoxic, togeher with cell viability demonstrated that the nanoliposomes are not toxic. Besides, in vivo assays not demonstrate toxicity in hematological and biochemical markers of young rats. Nevertheless, increase content of creatine in the cerebral cortex tissue after subchronic treatment was observed. Altogether, results indicate increase permeability of creatine to the BBB that could be used as assay for in vivo studies to confirm improved effect than free creatine.
\end{abstract}

Key words: nanocarrier, neurodegenerative diseases, nanotechnology, liposomes.

\footnotetext{
Correspondence to: Carina Rodrigues Boeck

E-mail: crboeck@gmail.com

* Contribution to the centenary of the Brazilian Academy of

Sciences.
} 


\section{INTRODUCTION}

Creatine contributes to energy homeostasis and ensures stable, locally buffered ATP/ADP ratios (Bessman and Carpenter 1985, Wallimann et al. 1992). Studies have demonstrated its protective effect on Alzheimer's, Parkinson's and Huntington disease animal models, besides oxidative damage (Malcon et al. 2000, Andres et al. 2005, Bender et al. 2005, Burklen et al. 2006, Hersch et al. 2006).

Neurodegenerative diseases are associated with neuronal cell loss due to processes such as excitotoxicity, oxidative stress, mitochondrial dysfunction, transcriptional dysregulation and aggregation of fibrillar proteins. Neuronal loss or dysfunction can lead to neurological diseases whose characteristics can determine disease progression (Beal 2011). Neurological diseases are induced by many primary factors leading to a characteristic secondary energy deficit in cell metabolism, that is responsible for calcium $\left(\mathrm{Ca}^{2+}\right)$ accumulation and increases the free radical levels in the cell. The process ends at cell death by necrosis and/or apoptosis (Wyss and Kaddurah-Daouk 2000, Schulze 2003). Oxidation reactions are an important factor in cerebral pathologies (Ames et al. 1993) because the brain has high oxygen consumption, making it more susceptible to the effects of oxidative stress than other tissues (Sah et al. 2002). In addition, a high concentration of polyunsaturated fatty acids in the brain facilitates initiation and development of oxidation processes, because they generate reactive substances when oxidized (Seviand and Mcleod 1997).

However, despite the physiological significance of creatine in the brain, its penetration in tissue is limited by the blood-brain barrier (BBB) (Béard and Braissant 2010). Thus, the use of nanostructured systems, such as nanoparticles, has become a promising strategy to increase drug permeability into tissue, facilitating transport across the BBB (Modi et al. 2009). Nanoliposomes with a modified surface are a system reported as good candidates for drug delivery into the central nervous system (CNS) (Omae et al. 2008, Ko et al. 2009, Qin et al. 2011). Nanoliposomes have an internal aqueous compartment being ideal for transporting hydrophilic molecules such as creatine (Edwards and Baeumner 2006, Cooper et al. 2012).

Thus, the objective of this study is to produce, characterize and evaluate the in vitro and in vivo toxicity of creatine nanoliposomes $(\mathrm{CrL})$ as a potencial alternative for the treatment of CNS damage.

\section{MATERIALS AND METHODS}

1,2-Distearoyl-sn-glycero-3-phosphocholine (DSPC); 1,2-distearoyl-sn-glycero-3hosphoethanolamine-n-[methoxy(polyethylene glycol)-2000] (DSPE-PEG 2000), was purchased from Lipoid ${ }^{\circledR}$ (Ludwigshafen, Germany); cholesterol, polyoxyethylenesorbitan monooleate (TWEEN $^{\circledR} 80$ ) and creatine were purchased from Sigma-Aldrich (St. Louis, MO, USA). For biochemical assays Labtest Diagnóstica ${ }^{\circledR}$ (Lagoa Santa, Brazil) was used. All other reagents were of commercial grade, and they were used as received unless otherwise noted. The solvents were dried and distilled according to procedures described in the literature before use.

\section{PREPARATION OF THE NANOLIPOSOME}

The nanoliposomes [blank (BL) or with creatine $(\mathrm{CrL})]$ were prepared using the ethanol injection method, similar to that described in Justo and Moraes (2005). Soybean phospholipids, cholesterol and DSPE-PEG 2000 were mixed in a mass ratio of 70/30/10. In brief, all lipid components were dissolved in $1 \mathrm{~mL}$ of ethanol, and then injected into $10 \mathrm{~mL}$ of a phosphate buffered saline solution (PBS, 10 mM, pH 7.4). Nanoliposomes were formed spontaneously, followed by stirring for $1 \mathrm{~h}$ at $50{ }^{\circ} \mathrm{C}$ to removal residual ethanol. The solution 
was then extruded (five times) using $200 \mathrm{~nm}$ poresize cellulose acetate membrane filters Millipore ${ }^{\circledR}$ (Massachusetts, USA) For preparing CrL, 100 mg creatine was first mixed with PBS before the ethanol injection step.

DYNAMIC LIGHT SCATTERING (DLS), POLYDISPERSITY INDEX AND ZETA POTENTIAL

The size, polydispersity and zeta potential of the liposomes were measured using ZETASIZER NANO-ZS, Malvern Instruments (Worcestershire, UK). The sample was illuminated by a $633 \mathrm{~nm}$ laser, and light scattered intensity was at a $173^{\circ}$ angle measured by avalanche photodiode. The measurements were performed in nanoliposome solution $100 x$ diluted in water at $25^{\circ} \mathrm{C}$. The results are the average of three measurements. Zeta potential was measured using the laser doppler velocimetry (LDV) technique. For zeta potential determination, three measurements were performed and the average was reported.

\section{TRANSMISSION ELECTRON MICROSCOPY (TEM)}

The transmission electron microscopy images were taken at the Electron Microscopy Center at the Federal University of Rio Grande do Sul (UFRGS). The size and morphology of the amphiphilic structure were recorded on Kodak SO163 film using an electron microscope (JEOL JEM Electronic Transmission 1200ExII) operating at $120 \mathrm{kV}$. The negatives were digitized using a Kodak Mega Plus CCD camera. To prepare TEM samples, $10 \mu \mathrm{L}$ of CrL were spread over a copper grid coated with carbon thin film. Preceding the complete drying, 10 $\mu \mathrm{L}$ of $2 \%(\mathrm{w} / \mathrm{v})$ uranyl acetate negative stain were added. The excess sample was removed with paper and the grid was allowed to dry.

HPLC MEASUREMENTS OF CREATINE CONCENTRATION

The concentration of creatine in nanoliposomal suspension was measured using a Shimadzu
Prominence apparatus with UV-Vis spectrophotometric detection and Phenomenex C18 column ( $15 \times 4.6 \mathrm{~mm}, 5 \mu \mathrm{m})$. The mobile phase was methanol-water (50:50, v/v), injection volume was $20 \mu \mathrm{L}$ and the column temperature was maintained at $25^{\circ} \mathrm{C}$. The analysis was performed at $0.8 \mathrm{~mL} / \mathrm{min}$ flow rate with UV detector at $210 \mathrm{~nm}$. The standard curve range was $(6.25-100 \mu \mathrm{g} / \mathrm{mL})$, quantification and detection limits were 3.39 and $1.13 \mu \mathrm{g} / \mathrm{mL}$ respectively. The encapsulation efficiency (E.E.) was measured by the ultrafiltration/centrifugation method (Ultrafree-MC ${ }^{\circledR}$ 10,000 MW, Millipore, Bedford, USA). E.E. was calculated as follows: E.E. $=($ total drug - free drug $) /$ total drug $\times 100$.

\section{BIOLOGICAL ASSAYS}

\section{Peripheral blood assay}

Human peripheral blood was collected using disposable sterile materials. Four millilitres of blood from 5 volunteers were utilized, collected and aliquoted in $1 \mathrm{~mL}$ per well in a total of 4 wells of a cell culture microplate with 12 wells. All experimental procedures were reviewed and approved by the Ethics Committee on Research of the University of the Far South of Santa Catarina State (UNESC- Universidade do Extremo Sul Catarinense), under protocol number 381,163. Cells ( $1 \mathrm{~mL}$ of blood) were treated with: PBS (negative control - NC), BL, $0.2 \mathrm{mg} / \mathrm{mL} \mathrm{CrL}$ or 0.2 $\mathrm{mg} / \mathrm{mL}$ creatine free $(\mathrm{Cr})$. The blood was incubated in a $5 \% \mathrm{CO}_{2}$ atmosphere at $37{ }^{\circ} \mathrm{C}$, and samples were collected after 8,24 and $48 \mathrm{~h}$ of incubation to perform cell viability and comet assay.

\section{Blood cell viability}

Cell blood viability was evaluated using the Trypan blue test performed as previously described (Martins et al. 2016). The test was carried out after 8, 24 and $48 \mathrm{~h}$ following incubation with $0.2 \mathrm{mg} / \mathrm{mL} \mathrm{BL}, \mathrm{CrL}$ or Cr. Then a cell blood suspension (lymphocytes) 
aliquot $(5 \mu \mathrm{L})$ was mixed in tubes with $5 \mu \mathrm{L}$ of $0.25 \%$ Trypan blue solution. The suspension was stirred, transferred to a hemocytometer, and covered with a coverslip. One hundred cells were evaluated in an optical microscope to determine the percentage of viable cells.

\section{Comet assay in blood cells}

The alkaline Comet assay was performed as described by Tice et al. (2000). Peripheral blood samples were collected 8, 24 and $48 \mathrm{~h}$ after mixture of BL, CrL or $\mathrm{Cr}(0.2 \mathrm{mg} / \mathrm{mL})$ with blood. Peripheral blood samples were collected in heparinized tubes and subsequently kept on ice. Blood cell aliquots (5 $\mu \mathrm{L}$ ) were embedded in $0.75 \%$ low melting agarose (w/v; $95 \mu \mathrm{L}$ ). This mixture was then deposited onto a microscope slide pre-coated with normal melting point agarose $(1.5 \%, \mathrm{w} / \mathrm{v})$ and furnished with a coverslip (two slides per sample). The slides were briefly placed on ice for the agarose to solidify, so that the coverslip could be carefully removed. Next, the base slide was immersed in freshly prepared lysis solution $(2.5 \mathrm{M} \mathrm{NaCl}, 100 \mathrm{mM}$ EDTA, 10 $\mathrm{mM}$ Tris, $\mathrm{pH}$ 10.0-10.5). Then, the slides were immersed for $20 \mathrm{~min}$ in freshly prepared alkaline buffer (300 mM NaOH, 1 mM EDTA, $\mathrm{pH}>13$ ) to be electrophoresed $(15 \mathrm{~min} / 300 \mathrm{~mA} ; 25 \mathrm{~V} ; 0.7$ $\mathrm{V} / \mathrm{cm}$ ) in the same buffer. All of these steps were carried out under minimal indirect light. Following electrophoresis, slides were neutralized in $400 \mathrm{mM}$ Tris ( $\mathrm{pH} 7.5)$ and stained with silver nitrate solution (Collins et al. 1997). To calculate the damage index (DI), cells were visually separated into five classes according to tail size (from $0=$ no tails to 4 = maximum-length tails). Accordingly, a single DNA damage score was obtained for each sample and consequently for each group studied. The DI for the group could range between 0 (completely undamaged $=100$ cells $\times 0$ ) and 400 (maximum damage $=100$ cells $\times 4)$. The damage frequency (DF in \%) was calculated for each sample, based on the number of cells with tail, compared to those without. Visual scoring of comet assays is considered a reliable evaluation method and usually results in high correlation values with computerbased image analysis methods Collins (2004). All slides were coded for blind analysis.

\section{Cell Viability in cultured Vero cells}

Tests were performed in 96 well plates, to which were added $2 \times 10^{4}$ cells of the Vero cell line (ATCC CCL-81 ${ }^{\mathrm{TM}}$ ) per well. Cell cultures were performed in RPMI 1640 medium (Gibco, Grand Island, NY, USA), supplemented with $10 \%$ fetal bovine serum, incubated with $0.02,0.2$ or $2 \mathrm{mg} / \mathrm{mL} \mathrm{CrL}$ or $\mathrm{Cr}$ at $37{ }^{\circ} \mathrm{C}$ in $5 \% \mathrm{CO}_{2}$ for 24 and $72 \mathrm{~h}$ to evaluate cell viability by the MTT reduction. Then, the culture medium was replaced with $180 \mu \mathrm{L}$ RPMI and 20 $\mu \mathrm{L}$ ( $10 \%$ of the culture medium volume) of MTT stock solution ( $5 \mathrm{mg} / \mathrm{mL}$ in PBS) and Vero cells were incubated for $4 \mathrm{~h}$ at $37{ }^{\circ} \mathrm{C}, 5 \% \mathrm{CO}_{2}$. Control cells were incubated only with culture medium. The absorbance at $570 \mathrm{~nm}$ was then measured using a microplate reader (TP Reader NM). Data are expressed as a percentage of the absorbance of cells treated with PBS (negative control $=\mathrm{NC}$ ) and $\mathrm{H}_{2} \mathrm{O}_{2}$ (positive control $=\mathrm{PC}$ ). The experiments were carried out in triplicate.

\section{LDH assay in cultured Vero cells}

The effect of treatments on the plasma membrane integrity of Vero cells was assessed by lactate dehydrogenase (LDH) assay (Decker and Lohmann-Matthes 1988). The activity of LDH in the medium was determined using a commercially available kit (Labtest Diagnostic, Lagoa Santa, Brazil). Vero cells were incubated with $0.02,0.2$ or $2 \mathrm{mg} / \mathrm{mL} \mathrm{CrL}$ or Cr, or $1 \%(\mathrm{v} / \mathrm{v})$ Triton X-100 (positive control $=$ PC) for $72 \mathrm{~h}$. The supernatants from cell cultures were removed and LDH released was determined by two-point enzymatic kinetics (Kaplan et al. 1988) the absorbance at $340 \mathrm{~nm}$ was determined in an SBA $200 \AA$ automated analyzer CELM (CELM, Barueri, SP, Brazil). 


\section{Experimental design of animal model toxicity}

Four dams (40-60 days) were used to obtain thirtytwo Wistar rats (7 days at start of treatment) in this experiment. Rats were kept with the dams while receiving the treatment until they were euthanized. The dams had free access to water and to a standard commercial chow (Guabi, RS, Brazil). Room temperature was maintained at $24 \pm 1{ }^{\circ} \mathrm{C}$, with a $12-12 \mathrm{~h}$ light-dark cycle. The animals were randomly assigned to four groups: Control group (C): rats received i.p administration of $0.85 \%$ saline twice a day; Creatine group (Cr): $200 \mathrm{mg} / \mathrm{kg}$ Cr i.p twice a day (total $400 \mathrm{mg} / \mathrm{kg} /$ day); BL group (BL): administration BL (proportional volume of CrL) i.p. twice a day; CrL group: $200 \mathrm{mg} / \mathrm{kg} \mathrm{CrL}$ i.p twice a day (total $400 \mathrm{mg} / \mathrm{kg} /$ day). After 13 days of treatment, animals were decapitated, serum and tissues were collected for hematological, biochemical and histological analysis. The "Principles of Laboratory Animal Care" (NIH publication 80-23, revised 1996) were followed in all the experiments. All animal procedures were approved by the Animal Ethics Committee from the Franciscan University (protocol under number: 006/2014).

\section{Haematological analysis in young rats}

Whole blood from young rats was collected (approximately $1.5 \mathrm{~mL}$ ) in tubes with ethylenediamine tetraacetic acid (EDTA) anticoagulant and homogenised. Immediately after this, erythrocytes (RBC), hemoglobin ( $\mathrm{Hb}$ ), hematocrit (Hct), mean corpuscular volume (MCV), mean corpuscular hemoglobin concentration (MCHC), platelet and leukocyte (WBC) were determined on the automated analyzer COULTER T890 ${ }^{\circledR}$ (Coulter Electronics, Inc. Hialeach, USA). Blood smears were fixed in methanol and stained with InstantProv (NewProv $\left.{ }^{\circledR}, \mathrm{PR}, \mathrm{Brazil}\right)$ to determine the differential leukocyte count.

\section{Biochemical analysis}

Approximately $1.5 \mathrm{~mL}$ of whole blood were collected from young rats and centrifuged at
$1700 \times \mathrm{x}$ or 15 minutes. Aspartate transaminase (AST), alanine transaminase (ALT) and, alkaline phosphatase (ALP) activities were determined, creatinine, urea, uric acid, total protein (TP) were measured in an SBA $200^{\circledR}$ automated analyzer CELM (SP, Brazil) using the commercial kits (Labtest Diagnostica SA, Lagoa Santa, Brazil).

\section{Histological examination of the tissues}

After the death of young rats, liver, kidney and spleen were dissected and prepared accordingly (Junqueira and Carneiro 2008). The samples were first dehydrated with ethanol (at increasing concentrations), then embedded in paraffin, and stained with hematoxylin and eosin. Images were obtained using a microscope.

\section{Creatine concentrations in the brain}

The brain samples from young rats were dissected and homogenized in 1:5 w/v Tris/HCl $50 \mathrm{mM}$ $(\mathrm{pH} 7.4)$ to obtain the supernatant $\left(\mathrm{S}_{1}\right)$ after tissue centrifugation at $2400 \times \mathrm{g}$ for $10 \mathrm{~min}$. For the determination of creatine in the tissue the colorimetric method was used, where $S_{1}$ supernatants from samples were added directly to a color of solution composed of $0.05 \%$ diacetyl, 1.5 $\mathrm{M} \mathrm{NaOH}, 2 \% \alpha$-naphthol; after 20 min the reaction of creatine was measured at $540 \mathrm{~nm}$ (Hughes 1962). Creatine levels are expressed in nmol of creatine per mg protein.

\section{Protein determination}

Total protein concentration was determined by the method of Bradford (1976), using bovine serum albumin as a standard.

\section{STATISTICAL ANALYSIS}

Results are expressed as mean \pm SEM. Statistical analysis of the data was obtained applying oneway analysis of variance (ANOVA), followed by Tukey's test. $\mathrm{p}<0.05$ was considered statistically significant. 


\section{RESULTS AND DISCUSSION}

\section{SYNTHESIS AND CHARACTERIZATION OF THE} LIPOSOMES

The liposomes obtained were analyzed for size (mean diameter), polydispersity index (PDI) Zeta potential and $\mathrm{pH}$, where readings were performed in triplicate (Table I). The nanoliposomes showed an average particle size of $213 \pm 13.7 \mathrm{~nm}$, PDI $0.237 \pm 0.03, \mathrm{pH} 7.3$, which are good results for biological applications (Wohlfart et al. 2011, Wang et al. 2009). The majority of particles obtained were at approximately $100 \mathrm{~nm}$ (analysis by number) with a peak width of $51 \mathrm{~nm}$, showing good homogeneity of the liposomes with PDI less than 0.3 (Figure 1b). TEM images showed CrL morphology in spherical vesicles and a well-defined shape (common characteristic of nanoliposome). A 100,000 fold increase (Figure 1a) confirmed the results obtained for particle size, where the majority of particles were sized at $100 \mathrm{~nm}$.

These results are interesting when the CNS is targeted, because a particle size for delivery of drugs to the CNS between 150-300 $\mathrm{nm}$ has been suggested (Hillaireau and Couvreur 2009, Wohlfart et al. 2011). Another possible alternative for increasing the circulation time (nanoliposome halflife) of particle is modifying its surface with higher hydrosoluble substances. Nanoliposome-coated PEG are the most used when stealthy characteristics are desired for the carrier (Milla et al. 2012). One possible explanation for increased half-life is due to steric stabilization that is generated by adding PEG to the surface of liposomes, preventing complement protein fixation (Allen et al. 1991).

In our study, we used the synthetic phospholipid DSPE-PEG 2000 and polysorbate 80 in order to improve the half-life and promote the adsorption of plasma apolipoproteins to facilitate endocytosis into brain capillaries (Friese et al. 2000, Modi et al. 2009), which would favor the nanoliposome movement and their penetration into the brain tissue.

Zeta potential values obtained from $-12.5 \mathrm{mV}$. The particle surface potential is very important to generate electrostatic repulsion force, which overcomes the natural tendency to aggregation (Robert et al. 1994). Usually, dispersions with high absolute zeta potentials are considered stable. However, in the case of nonionic surfactants, it has been shown that stability is achieved by steric repulsion (Muller et al. 2000). Negatively loaded nanoliposomes have shown a shorter half-life in the bloodstream compared to neutral nanoliposomes. Although positively charged nanoliposomes also demonstrate this higher opsonization as a negative, both have been shown to activate the immune system, but by different routes (Immordino et al. 2006). In our study, we used the synthetic phospholipid DSPE-PEG 2000 and polysorbate 80 in order to improve circulation time and promote the adsorption of plasma apolipoproteins capable of facilitating endocytosis by cerebral capillaries (Friese et al. 2000, Modi et al. 2009).

The E.E. was approximately $32 \%$. This result is above the average obtained for the encapsulation of hydrophilic drugs (Fattal et al. 1995). Although the association rate is not high, nanotechnology has shown better results with lower concentrations of drugs (Wohlfart et al. 2011). The present and other results in the physicochemical characterization demonstrate the technological feasibility of CrL.

\section{TOXICITY IN CULTURED VERO CELLS}

Vero cell viability did not change after exposition to $0.02 ; 0.2$ or $2 \mathrm{mg} / \mathrm{mL}$ Cr. Nanoliposomes with 2 $\mathrm{mg} / \mathrm{mL}$ creatine induced reduction in cell viability to $84.9 \%$ after 24 h (Figure $2 \mathrm{a}$ ) and $93.5 \%$ after $72 \mathrm{~h}$ (Figure $2 \mathrm{~b}$ ) of incubation. The same effect was observed for blank liposomes that induced a reduction of $77.7 \%$ at $24 \mathrm{~h}$ (Figure $2 \mathrm{a}$ ) and $93.2 \%$ at $72 \mathrm{~h}$. The LDH assay confirms cell death 
a

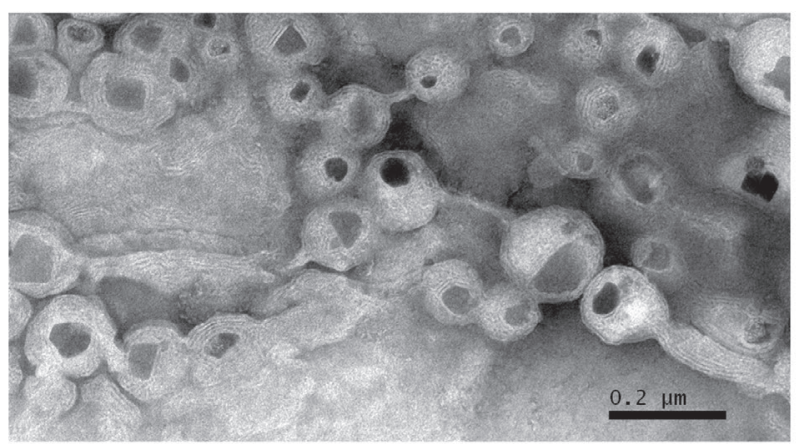

b

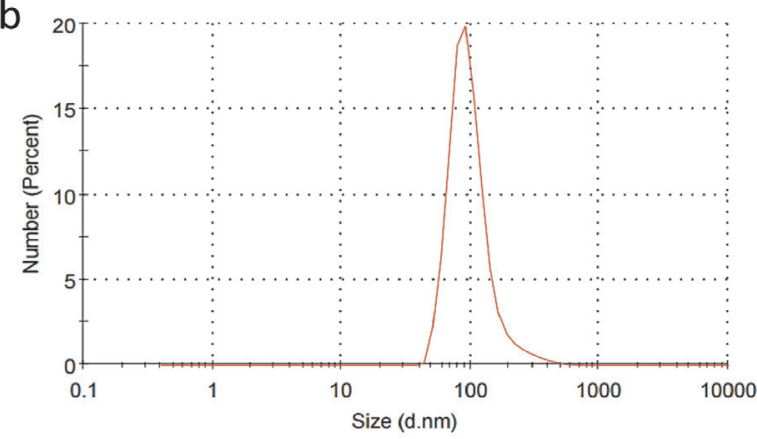

Figure 1 - (a) Image obtained by transmission electron microscopy. Bar corresponds to $200 \mathrm{~nm}$. (b) The average size distribution of the nanoliposomes is represented in the graphic.

TABLE I

Characterization of BL and CrL.

\begin{tabular}{lcc}
\hline & BL & CrL \\
\hline Mean diameter (nm) & $225 \pm 5.3$ & $213 \pm 13.7$ \\
Polydispersity index & $0.267 \pm 0.02$ & $0.237 \pm 0.03$ \\
Zeta potential (mV) & $-22.5 \pm 1.9$ & $-12.5 \pm 2.3^{*}$ \\
pH & $7.3 \pm 0.1$ & $7.3 \pm 0.2$ \\
E.E. (\%) & - & $32 \pm 3$ \\
\hline
\end{tabular}

$* \mathrm{p}<0.05$. compared to BL. Student's t-test.

provoked at the highest concentrations $(2 \mathrm{mg} / \mathrm{mL})$ (Figure 2c). Studies have shown that even high concentrations $(10 \mathrm{mM})$ of creatine do not present neurotoxicity (Genius et al. 2012), which is in agreement with the results obtained in the present work in the treatments with free creatine. The high concentrations of phospholipids and surfactants present at the highest concentrations are probably responsible for cell death.

Gasparri et al. (2011) observed Vero cell viability treated with different liposome formulations for $24 \mathrm{~h}$, where there was no change in viability in any treatment groups. However, there was a reduction in viability of cationic liposomes within 48 hours. In this study the liposomes had a 10 to 30 fold greater particle size, which may explain the observed differences.

Blood cell viability was evaluated by Trypan blue assay, where no changes were observed in any treatment group or incubation period. The DNA damage frequency and index were evaluated by comet assay, which also did not show change in all groups or incubation period (Table II).

The concentration used for the comet test and cell viability test by Trypan blue was $0.2 \mathrm{mg} / \mathrm{mL}$, the results are in accordance with those observed in the Vero cell viability tests, demonstrating that the nanoliposomes are non-toxic and can be used for biological application. The data from the comet assay were similar to those obtained with Trypan blue for blood cell viability, and demonstrated that $\mathrm{CrL}$ were not genotoxic under the conditions evaluated. The alkaline $(\mathrm{pH}>13)$ assay is able to detect single-strand breaks (SSB), alkali-labile sites (ALS), DNA-DNA and DNA-protein cross-linking and SSB associated with incomplete repair excision sites. When compared with other genotoxicity tests, comet has shown great sensitivity for the detection of low levels of DNA damage (Tice et al. 2000).

\section{ANIMAL MODEL TOXICITY}

The haematopoietic system is sensitive to toxic agents and much used to evaluate pathological processes in animals as a good peripheral toxicity marker (Wang et al. 2014). The blood count and non-cellular components are important criteria to assess homeostasis, and special changes resulting from pathological or experimental procedures (George and Santos 2011). In our studies we did not find any significant changes in hematological 


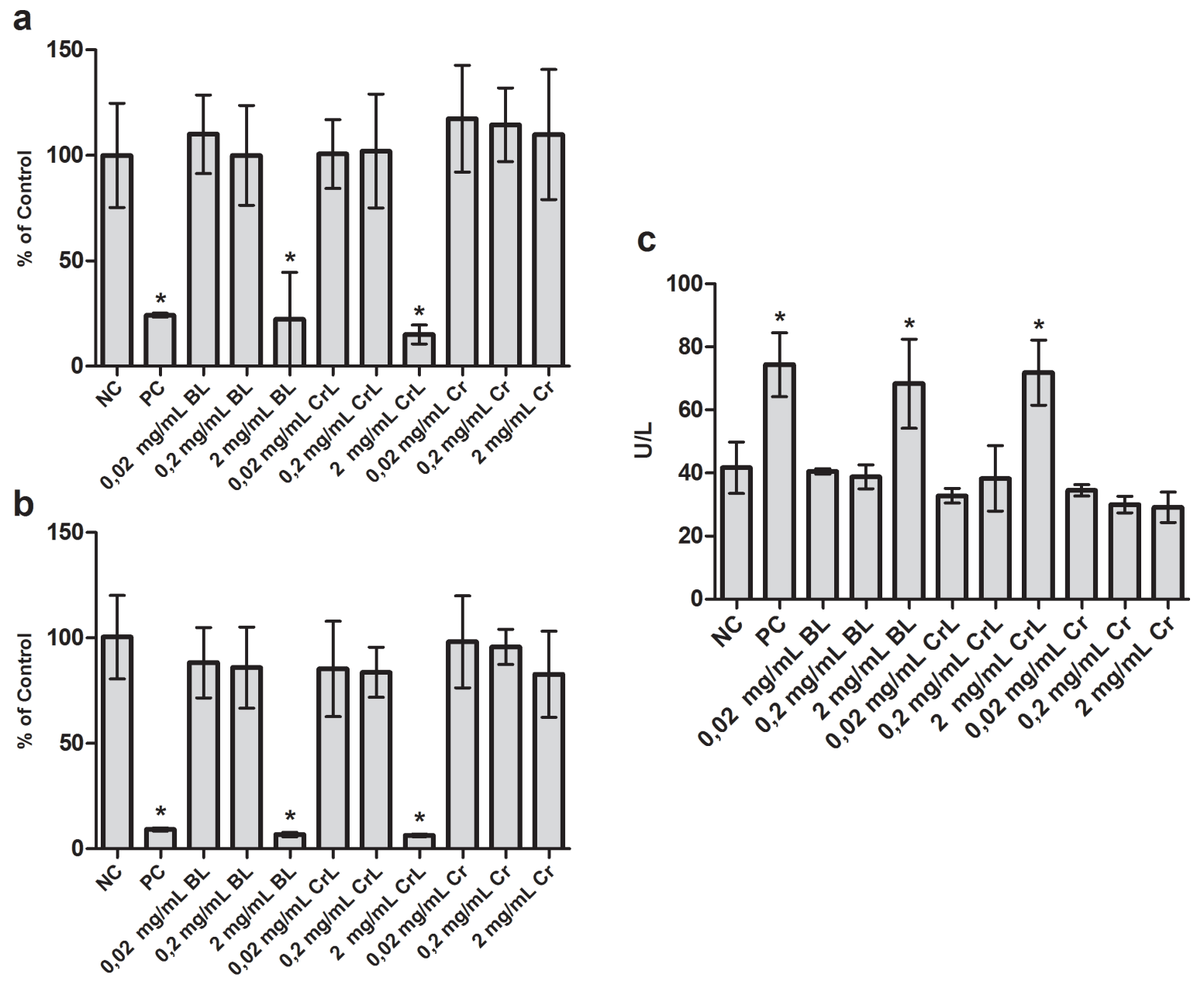

Figure 2 - MTT reduction in Vero cells after 24 (a) or 72 h (b) of treatment with CrL. (c) LDH activity in Vero cells. Negative Control (NC), Blank Liposomes (BL), Creatine Liposomes (CrL), Creatine (Cr). Results are expressed as percentage of the control ( $100 \%$ cell viability). Bars represent mean $\pm \mathrm{SD}$. ${ }^{*} \mathrm{p}<0.05$ compared to NC.

TABLE II

Effect of different treatments with creatine on cell viability and genotoxicity.

\begin{tabular}{|c|c|c|c|c|c|}
\hline & Time (h) & NC & BL & CrL & $\mathrm{Cr}$ \\
\hline \multirow{3}{*}{ Viability (\%) } & 8 & 100 & 100 & 100 & 100 \\
\hline & 24 & $99,8 \pm 0,45$ & 100 & $99,8 \pm 0,45$ & $99,8 \pm 0,45$ \\
\hline & 48 & $99,6 \pm 0,54$ & $99,8 \pm 0,45$ & $99,8 \pm 0,45$ & $99,8 \pm 0,45$ \\
\hline \multirow{3}{*}{ Damange index } & 8 & nd & nd & nd & $0,2 \pm 0,45$ \\
\hline & 24 & nd & nd & nd & $0,6 \pm 1,34$ \\
\hline & 48 & nd & nd & nd & $0,6 \pm 1,34$ \\
\hline \multirow{3}{*}{ DNA damage } & 8 & nd & nd & nd & $0,2 \pm 0,45$ \\
\hline & 24 & nd & nd & nd & $0,6 \pm 1,34$ \\
\hline & 48 & nd & nd & nd & $0,6 \pm 1,34$ \\
\hline
\end{tabular}

Negative Control (NC), Blank Liposome (BL), Creatine Liposome (CrL), Creatine (Cr). mean \pm SD. No significant difference. nd $=$ not defined. 
parameters among experimental groups in young rats (Table III).

In view of the different markers of hepatic toxicity used in the present study, none of them was altered after treatment with $\mathrm{CrL}$ or BL, even when administered at higher concentrations, more than can be expected for effective treatment in animal models of damage to the CNS (Table IV). Serum AST and ALT levels are used as liver function biomarkers, because any lesion can elevate the levels of these enzymes in the bloodstream, and they are therefore good markers of hepatic toxicity (Nalpas et al. 1986). FAL is responsible for the removal process of the phosphate group, which is called dephosphorylation. Its levels are high in children and pregnant women or in pathologies that affect the bile ducts, so it is also used as a marker of hepatobiliary diseases (Motta 2009). PTs consist of albumin and globulin fractions. Low levels of these plasma constituents may be related to liver disease or acute infection. Due to being produced mainly in the liver, low levels of these proteins demonstrate changes in liver function (Baynes and Dominiczak 2010).

Analysing different renal function markers, no changes were observed in any of the treatment groups of young rats. These data on the levels of urea, creatinine and uric acid indicate that the creatine nanoliposomes do not induce renal damage (Table IV). Urea participates in the elimination of nitrogen from the organism and in a complex system of water and ions reabsorption, essential to maintenance of the metabolism. Urea levels elevated in the bloodstream are related to renal damage or increased protein catabolism, however, their reduction is related to hepatic impairment

TABLE III

Effect of different treatments with creatine on hematological parameters.

\begin{tabular}{|c|c|c|c|c|}
\hline & NC & BL & CrL & $\mathrm{Cr}$ \\
\hline $\mathrm{RBC}\left(\mathrm{x} 10^{6} / \mu \mathrm{L}\right)$ & $4.00 \pm 0.29$ & $4.18 \pm 0.66$ & $3.83 \pm 0.37$ & $3.53 \pm 0.90$ \\
\hline HGB $(\mathrm{g} / \mathrm{dL})$ & $9.8 \pm 1.1$ & $9.9 \pm 0.4$ & $9.1 \pm 0.6$ & $9.7 \pm 0.9$ \\
\hline $\operatorname{HCT}(\%)$ & $26.1 \pm 1.9$ & $26.0 \pm 4.2$ & $24.9 \pm 2.7$ & $25.0 \pm 5.2$ \\
\hline $\operatorname{PLT}\left(\mathrm{x} 10^{3} / \mu \mathrm{L}\right)$ & $1020 \pm 445$ & $933 \pm 387$ & $1104 \pm 276$ & $1081 \pm 216$ \\
\hline VCM (fl) & $66.2 \pm 4.8$ & $65.5 \pm 4.3$ & $65.0 \pm 3.5$ & $68.5 \pm 3.1$ \\
\hline CHCM (\%) & $36.2 \pm 4.1$ & $36.5 \pm 5.3$ & $37.1 \pm 5.0$ & $37.4 \pm 4.6$ \\
\hline $\mathrm{WBC}\left(\mathrm{x} 10^{3} / \mu \mathrm{L}\right)$ & $6.4 \pm 1.2$ & $5.3 \pm 1.5$ & $6.1 \pm 1.5$ & $5.6 \pm 1.4$ \\
\hline Lymphocytes (\%) & $71.5 \pm 6.1$ & $70.5 \pm 5.1$ & $69.7 \pm 3.3$ & $70.3 \pm 4.9$ \\
\hline Neutrophil (\%) & $21.7 \pm 2.9$ & $22.3 \pm 4.6$ & $23.1 \pm 3.8$ & $22.6 \pm 3.8$ \\
\hline Eosinophils (\%) & $1.1 \pm 0.9$ & $0.8 \pm 0.7$ & $1.0 \pm 0.7$ & $1.2 \pm 1.0$ \\
\hline Monocytes (\%) & $5.7 \pm 3.2$ & $6.3 \pm 1.4$ & $6.1 \pm 1.7$ & $5.9 \pm 1.9$ \\
\hline
\end{tabular}

TABLE IV

Effect of different treatments on biochemical parameters.

\begin{tabular}{ccccc}
\hline & NC & BL & CrL & Cr \\
\hline AST (U/L) & $315 \pm 36.6$ & $290 \pm 17.8$ & $311 \pm 45.4$ & $324 \pm 26.1$ \\
ALT (U/L) & $42 \pm 4.7$ & $40 \pm 2.9$ & $43 \pm 7.2$ & $42 \pm 4.4$ \\
FAL (U/L) & $320 \pm 63.5$ & $266 \pm 28.7$ & $270 \pm 53.3$ & $305 \pm 72.6$ \\
PT (g/dL) & $6.5 \pm 0.88$ & $7.0 \pm 0.83$ & $7.1 \pm 0.59$ & $6.8 \pm 0.72$ \\
Urea (mg/dL) & $50.2 \pm 13.1$ & $49.4 \pm 4.9$ & $50.5 \pm 9.5$ & $51.2 \pm 7.7$ \\
Creatinine (mg/dL) & $0.51 \pm 0.04$ & $0.44 \pm 0.08$ & $0.46 \pm 0.16$ & $0.60 \pm 0.17$ \\
Uric acid (mg/dL) & $2.17 \pm 0.39$ & $2.14 \pm 0.49$ & $2.12 \pm 0.35$ & $2.55 \pm 0.72$ \\
\hline
\end{tabular}


(Traynor et al. 2006). Creatinine is the final product of creatine degradation, which is synthesized primarily in the liver and can also be obtained by diet (Wyss and Kaddurah-Daouk 2000). Creatinine is eliminated at a constant rate by kidneys, thus increased serum levels may indicate loss of renal function (Shemesh et al. 1985). Uric acid originates in the catabolism of purines, it is formed mainly in the liver. Approximately two-thirds of plasma uric acid are eliminated by the kidneys, and for this reason the uric acid levels increase may be related to renal function reduction (Smith et al. 2007, Lima et al. 2008).

Histological analyses in the liver, kidney and spleen tissue indicate that no changes occurred in all treatment groups in young rats (Figure 3 ). The histological data corroborates results from biochemical markers of liver and kidney toxicity.
The absence of changes in the spleen is in agreement with the results obtained by hematological tests.

The dose used in the in vivo toxicity model corresponds approximately to $0.2 \mathrm{mg} / \mathrm{mL}$ of the in vitro treatment. A therapeutic dose would correspond to the lower in vitro treatment $(0.02 \mathrm{mg} / \mathrm{mL})$. With this we can predict the safety of the carrier.

\section{CREATINE CONCENTRATION IN THE CNS OF ANIMALS}

Creatine concentrations measured in cerebral cortex from young rats showed one of the most important results, because animals treated with CrL had higher levels when compared to animals treated with $\mathrm{Cr}$ (Figure 4). The data suggests the effectiveness of the carrier, but further studies are needed to confirm this activity. Treatments with free creatine have shown debatable results,

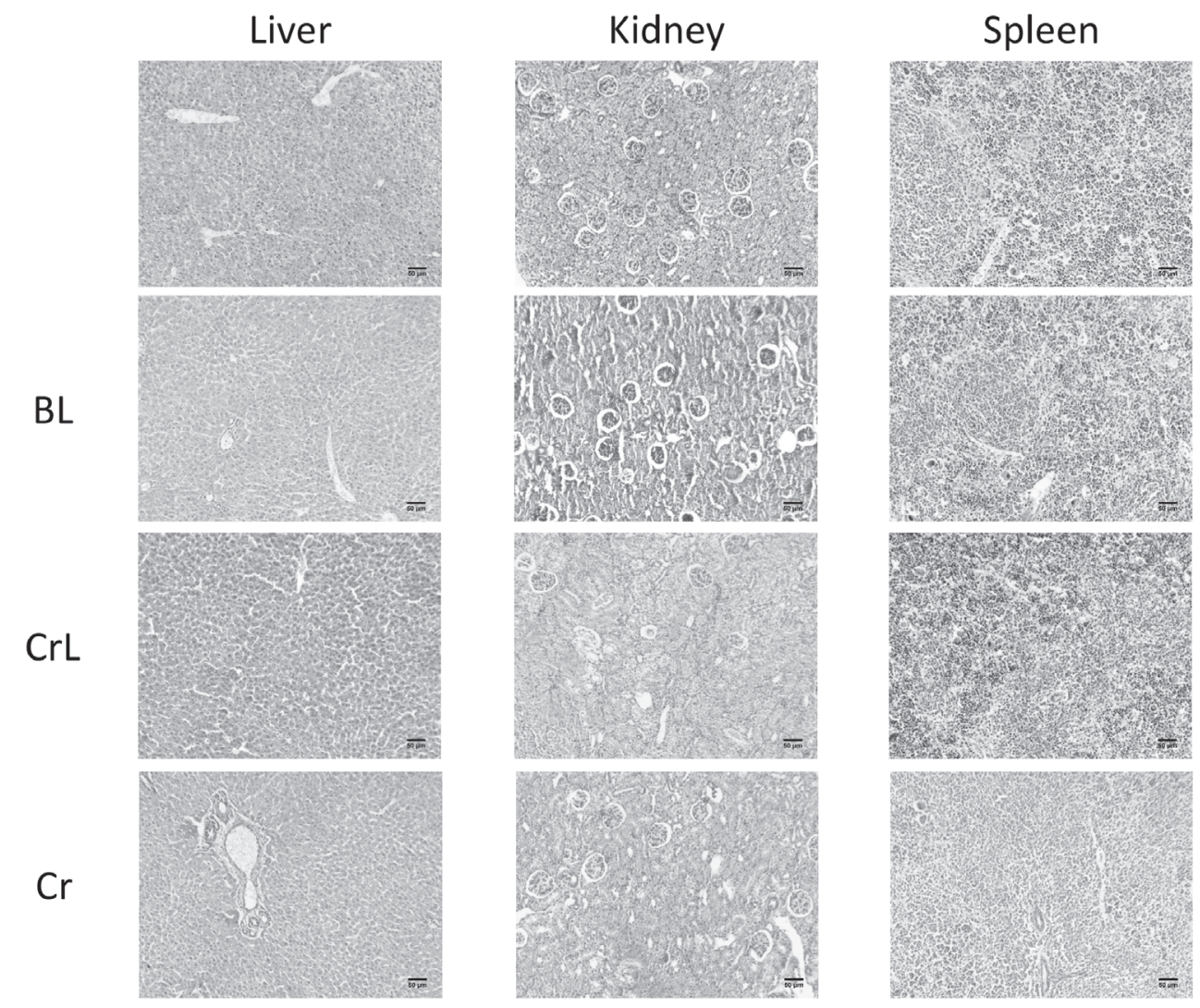

Figure 3 - Histological analysis of liver, kidney and spleen of treated rats. Negative Control (NC), Blank Liposomaes (BL), Creatine Liposomes (CrL), Creatine (Cr). 


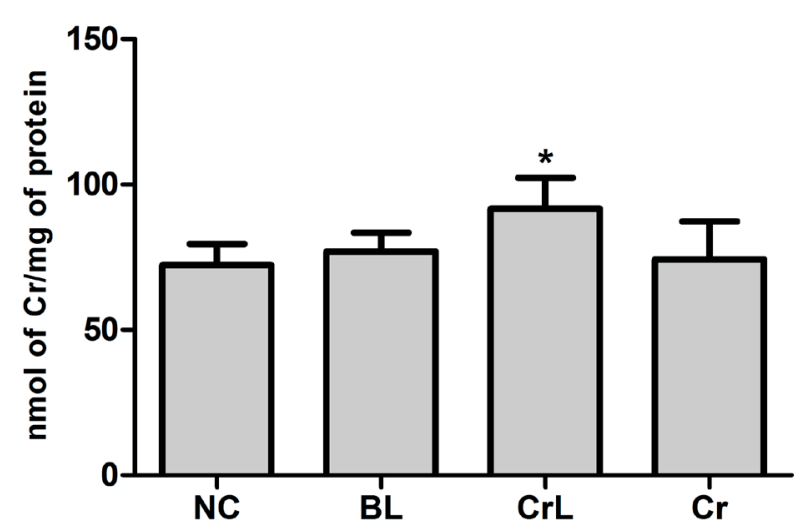

Figure 4 - Creatine concentration in cerebral cortex from adult rats treated. Negative Control (NC), Blank Liposomaes (BL), Creatine Liposomes $(\mathrm{CrL})$, Creatine $(\mathrm{Cr}) .{ }^{*} \mathrm{p}<0.05$, compared to the NC.

since intracerebroventricular treatments present superior results (Lensman et al. 2006). There are also different studies demonstrating the difficulty of creatine permeation through the BBB because of the absence of transporters in astrocytes (Hanna-elDaher and Braissant 2016). In another study using the same dose of $\mathrm{Cr}$ (400 mg/kg), authors showed an increase in creatine levels in the cerebral cortex from young rats treated for 13 days, but by the subcutaneous route. The authors concluded that this increase would indicate that, at that age, creatine would be transported to the brains of animals (De Andrade et al. 2015). Creatine concentrations were evaluated in cardiac and skeletal muscle, where no changes were observed (results not shown).

\section{CONCLUSIONS}

The synthesis of a new PEG-coated nanoliposome and its self-assembly into nanoparticles in phosphate buffer were successfully performed by the ethanol injection method. The data evidenced the size of nanoliposomes size in an appropriate average of $213 \mathrm{~nm}$ and monodisperse particles (0.237) with a negative zeta potential, which would be interesting for a biological application. This size was verified and confirmed by MET showing spherical particles of about $100 \mathrm{~nm}$. The new CrL did not alter cell viability at usual concentrations $(0.02$ and $0.2 \mathrm{mg} /$ $\mathrm{mL}$ ), nor induced genotoxicity and liver, kidneys and spleen toxicity. The most relevant data from CrL was its elevated level in the cerebral cortex from rats treated, indicating higher permeability into the CNS.

\section{ACKNOWLEDGMENTS}

The authors wish to thank the Conselho Nacional de Desenvolvimento Científico e Tecnológico (CNPq, Brazil) and Fundação de Amparo à Pesquisa do Estado do Rio Grande do Sul (FAPERGS) for financial support.

\section{REFERENCES}

ALLEN TM, HANSEN C, MARTIN F, REDEMANN C AND YAU-YOUNG A. 1991. Liposomes containing synthetic lipid derivatives of poly(ethylene glycol) show prolonged circulation half-lives in vivo. Biochim Biophys Acta 1066: 29-36.

AMES BN, SHIGENAGA MK AND HAGEN TM. 1993. Oxidants, antioxidants and the degenerative diseases of aging. Proc Natl Acad Sci 90: 7915-7922.

ANDRES RH, DUCRAY AD, PEREZ-BOUZA A, SCHLATTNER U, HUBER AW, KREBS SH, SEILER RW, WALLIMANN T AND WIDMER HR. 2005. Creatine supplementation improves dopaminergic cell survival and protects against MPP+ toxicity in an organotypic tissue culture system. Cell Transplant 14: 537-550.

BAYNES JW AND DOMINICZAK MH. 2010. Bioquímica Médica. $3^{\text {a }}$ ed., Rio de Janeiro: Elsevier, 386 p.

BEAL MF. 2011. Neuroprotective effects of creatine. Amino Acids 40: 1305-1313.

BÉARD E AND BRAISSANT O. 2010. Synthesis and transport of creatine in the CNS: importance for cerebral functions. J Neurochem 115: 297-313.

BENDER A ET AL. 2005. Creatine supplementation lowers brain glutamate levels in Huntington's disease. J Neurol 252: 36-41.

BESSMAN SP AND CARPENTER CL. 1985. The creatinecreatine phosphate energy shuttle. Annu Rev Biochem 54: 831-862.

BRADFORD MM. 1976. A rapid and sensitive method for the quantitation of microgram quantities of protein utilizing the principles of protein-dye binding. Anal Biochem 72: 248-254.

BURKLEN TS, SCHLATTNER U, HOMAYOUNI R, GOUGH K, RAK M, SZEGHALMI A AND 
WALliMANN T. 2006. The Creatine Kinase/Creatine Connection to Alzheimer's Disease: CK-Inactivation, APP-CK Complexes and Focal Creatine Deposits. J Biomed Biotechnol 2006: 1-11.

COLLINS A, DUSINSKÁ $M$, FRANKLIN $M$, SOMOROVSKÁ M, PETROVSKÁ H, DUTHIE S, FILLION L, PANAYIOTIDIS M, RASLOVÁ K AND VAUGHAN N. 1997. Comet Assay in Human Biomonitoring Studies:Reliability, Validation, and Applications. Environ Mol Mutagen 30: 139-146.

COLLINS AR. 2004. The comet assay for DNA damage and repair. Mol Biotechnol 26: 249-261.

COOPER R, NACLERIO F, ALLGROVE J AND JIMENEZ A. 2012. Creatine supplementation with specific view to exercise/sports performance: an update. J Int Soc Sports Nutr 9: 33.

DE ANDRADE RB, GEMELLI T, ROJAS DB, BONORINO NF, COSTA BML, FUNCHAL C, DUTRA-FILHO CS AND WANNMACHER CMD. 2015. Creatine and Pyruvate Prevent the Alterations Caused by Tyrosine on Parameters of Oxidative Stress and Enzyme Activities of Phosphoryltransfer Network in Cerebral Cortex of Wistar Rats. Mol Neurobiol 51: 1184-1194.

DECKER T AND LOHMANN-MATTHES M L. 1988. A quick and simple method for the quantitation of lactate dehydrogenase release in measurements of cellular cytotoxicity and tumor necrosis factor (TNF) activity. J Immunol Methods 115: 61-69.

EDWARDS KA AND BAEUMNER AJ. 2006. Liposomes in analyses. Talanta, London, 68: 1432-1441.

FATTAL E, RAMALDES GA AND OLLIVON M. 1995. Oral delivery of vaccines by means of liposomes. In: Puisieux F, Couvreur P, Delattre J and Devissaguet JP (Eds), Liposomes, new systems and trends in their applications. Paris: Editions de Santé, p. 693-710.

FRIESE A, SEILLER E, QUACK G, LORENZ B AND KREUTER J. 2000. Increase of the duration of the anticonvulsive activity of a novel NMDA receptor antagonist using poly(- butylcyanoacrylate) nanoparticles as a parenteral controlled release system. Eur J Pharm Biopharm 49: 103-109.

GASPARRI J, SPERONI L, CHIARAMONI NS AND ALONSOR SV. 2011. Relationship between the adjuvant and cytotoxic effects of the positive charges and polymerization in liposomes. J Liposome Res 21: 124-133.

GENIUS J, GEIGER J, BENDER A, MOLLER H, KLOPSTOCK T AND RUJESCU D. 2012. Creatine protects against excitoxicity in an in vitro model of neurodegeneration. PLoS ONE 7: e30554.

GEORGE T AND SANTOS H. 2011. Parâmetros Bioquímicos e Hematológicos de Ratos Wistar e Camundongos Swiss do Biotério. Rev Bras Ciênc Saúde 15: 209-214.
HANNA-EL-DAHER LAND BRAISSANT O. 2016. Creatine synthesis and exchanges between brain cells: What can be learned from human creatine deficiencies and various experimental models? Amino Acids 48: 1877-1895.

HERSCH SM ET AL. 2006. Creatine in Huntington disease is safe, tolerable, bioavailable in brain and reduces serum. Neurology 66: 250-252.

HILLAIREAU H AND COUVREUR P. 2009. Nanocarriers entry into the cell: relevance to drug delivery. Cell Mol Life Sci 66: 2873-2896.

HUGHES BP. 1962. A method for estimation of serum creatine kinase and its use in comparing creatine kinase. Clin Chim Acta 7: 597-603.

IMMORDINO ML, DOSIO F AND CATTEL L. 2006. Stealth liposomes: Review of the basic science, rationale, and clinical applications, existing and potential. Int $\mathrm{J}$ Nanomedicine 1: 297-315.

JUNQUEIRA LC AND CARNEIRO J. 2008. Histologia básica. $11^{\mathrm{a}}$ ed., Rio de Janeiro: Guanabara Koogan, 524 p.

JUSTO OR AND MORAES AM. 2005. Kanamycin incorporation in lipid vesicles prepared by ethanol injection designed for tuberculosis treatment. J Pharmacol Pharmacother 57: 23-30.

KAPLAN A, SZABO LL AND OPHEIM KE. 1988. Clinical Chemistry. $3^{\text {rd }}$ ed., Philadelphia: Lea \& Febiger, p. 185189.

KO YT, BHATTACHARYA R AND BICKEL U. 2009. Liposome encapsulated polyethylenimine/ODN polyplexes for brain targeting. J Control Release 133: 230237.

LENSMAN M, KORZHEVSKII DE, MOUROVETS VO, KOSTKINB VB, IZVARINAA N, PERASSOC L, GANDOLFOC C, OTELLINB VA, POLENOVA SA AND BALESTRINO M. 2006. Intracerebroventricular administration of creatine protects against damage by global cerebral ischemia in rat. Brain research 1114: 187194.

LIMA AO, DOARES JB AND GREGO J. 2008. Métodos de laboratório Aplicados à clínica. $8^{\mathrm{a}}$ ed., Rio de Janeiro: Guanabaa Koogan, 664 p.

MALCON C, KADDURAH-DAOUK R AND BEAL MF. 2000. Neuroprotective effects of creatine administration against NMDA and malonate toxicity. Brain Research 860: 195-198.

MODI G, PILLAY V, CHOONARA YE, NDESENDO VMK, DU TOIT LC AND NAIDOO D. 2009. Nanotechnological applications for the treatment of neurodegenerative disorders. Progress in Neurobiology 88: 272-285.

MARTINS CM, HAMANAKA EF, HOSHIDA TY, SELLAM, HIDALGO MM, SILVEIRA CS AND POI WR. 2016. Dragon's Blood Sap (Croton Lechleri) As Storage Medium For Avulsed Teeth: In Vitro Study Of Cell Viability. Braz Dent J 27: 751-756. 
MILLA P, DOSIO F AND CATTEL L. 2012. PEGylation of proteins and liposomes: a powerful and flexible strategy to improve the drug delivery. Curr Drug Metab 13: 105-119.

MOTTA VT. 2009. Bioquímica clínica para o laboratório: princípios e interpretações. $5^{\mathrm{a}}$ ed., Rio de Janeiro: Medbook, 419 p.

MULLER RH, MADER K AND GOHLA S. 2000. Solid lipid nanoparticles (SLN) for controlled drug delivery - a review of the state of the art. Eur J Pharm Biopha 50: 161-177.

NALPAS B, VASSAULT A, CHARPIN S, LACOUR B AND BERTHELOT P. 1986. Serum mitochondrial aspartate aminotransferase as a marker of chronic alcoholism: diagnostic value and interpretation in a liver unit. Hepatology 6: 608-614.

OMAE T, YOSHIOKA H, TANAKA T, NAGAI H, SAJI M, NODA K, KOBAYASHI S AND SUGIMOTO T. 2008. Antisense in vivo knockdown of synaptotagmin I by HVJliposome mediated gene transfer attenuates ischemic brain damage in neonatal rats. Brain Dev 30: 313-320.

QIN Y ET AL. 2011. Liposome formulated with TAT-modified cholesterol for improving brain delivery and therapeutic efficacy on brain glioma in animals. Int J Pharm 20: 304312.

ROBERT JP, BERGSTROM L AND DEKKER M. 1994. Surface and colloid chemistry in advanced ceramic processing. Surfactant Science Series 51: 136 p.

SAH R, GALEFFI F, AHRENS R, JORDAN G AND SCHWARTZ-BLOOM RD. 2002. Modulation of the GABA(A)-gated chloride channel by reactive oxygen species. J Neurochem 80: 383-391.

SCHULZE A. 2003. Creatine deficiency syndromes. Mol Cell Biochem 244: 143-150.

SEVIAND A AND MCLEOD L. 1997. Formation and biological reactivity of lipid peroxidation products. Free Radical Toxicology, Taylor \& Francis, p. 47-70.
SHEMESH O, GOLBETZ H, KRISS JP AND MYERS BD. 1985. Limitations of creatinine as a filtration marker in glomerulopathic patients. Kidney Int 28: 830-838.

SMITH C, MARKS DA AND LIEBERMAN M. 2007. Bioquímica Médica Básica de Marks. 2a ed., Porto Alegre: Artmed, $384 \mathrm{p}$.

TICE RR, AGURELL E, ANDERSON D, BURLINSON B, HARTMANN A, KOBAYASHI H, MIYAMAE Y, ROJAS E, RYU JC AND SASAKI YF. 2000. Single cell gel/comet assay: guidelines for in vitro and in vivo genetic toxicology testing. Environ Mol Mutagen 35: 206-221.

TRAYNOR J, MACTIER R, GEDDES CC AND FOX JG. 2006. How to measure renal function in clinical practice. BMJ 333: 733-737.

WALLIMANN T, WYSS M, BRDICZKA D, NICOLAY K AND EPPENBERGER HM. 1992. Intracellular compartmentation, structure and function of creatine kinase isoenzymes in tissues with high and fluctuating energy demands: the phosphocreatine circuit for cellular energy homeostasis. Biochem J 281: 21-40.

WANG CX, HUANG LS, HOU LB, JIANG L, YAN ZT, WANG YL AND CHEN ZL. 2009. Antitumor effects of polysorbate- 80 coated gemcitabine polybutylcyanoacrylate nanoparticles in vitro and its pharmacodynamics in vivo on C6 glioma cells of a brain tumor model. Brain Research 1261: 91-99.

WANG L, LI Z, LI L, LI Y, YU M, ZHOU Y, LV X, ARAI H AND XU Y. 2014. Acute and sub-chronic oral toxicity profiles of the aqueous extract of Cortex Dictamni in mice and rats. J Ethnopharmacol 158: 207-215.

WOHLFART S, GELPERINA S AND KREUTER J. 2011. Transport of drugs across the blood-brain barrier by nanoparticles. J Control Release 161: 264-273.

WYSS M AND KADDURAH-DAOUK R. 2000. Creatine and creatinine metabolism. Physiol Rev 80: 1107-1213. 